University of South Carolina

Scholar Commons

\title{
End of Program Assessments and their Association with Early Career Success in LIS
}

Susan R. Rathbun-Grubb

University of South Carolina - Columbia, srathbun@mailbox.sc.edu

Follow this and additional works at: https://scholarcommons.sc.edu/libsci_facpub

Part of the Library and Information Science Commons

\section{Publication Info}

Postprint version. Published in Journal of Education for Library and Information Science, Volume 57, Issue 1, 2016, pages 43-56.

(c) Journal of Education for Library \& Information Science, Association for Library and Information Science Education, 2016

This Article is brought to you by the Information Science, School of at Scholar Commons. It has been accepted for inclusion in Faculty Publications by an authorized administrator of Scholar Commons. For more information, please contact digres@mailbox.sc.edu. 


\title{
End of Program Assessments and their Association with Early Career Success in LIS
}

Susan Rathbun-Grubb. School of Library and Information Science, University of South Carolina, Email: srathbun@mailbox.sc.edu

\begin{abstract}
Analyses of North American LIS program alumni survey data indicate that the completion of any end of program assessment (EPA) or capstone is associated with certain early-career success measures. Using data collected in the Workforce Issues in Library and Information Science 2 project (WILIS 2), we examined the type of EPAs (internships, portfolios, theses, etc.) completed by students and assessed whether there are relationships between their completion and the following outcomes: length of time to secure employment after graduation, acquisition of managerial or leadership roles, job/career satisfaction, and participation in professional and leadership activities. We also assessed the graduates' attitudes about whether these experiences were a beneficial part of their career preparation. These results should be of interest to faculty curriculum developers and program administrators in LIS programs worldwide, since they provide insight into the relative merits of EPAs and are based on aggregate data from 39 programs and over 3,000 graduates.
\end{abstract}

\section{Keywords}

LIS internships, student portfolios, end of program assessments, pre-employment experiences, career satisfaction, career success 
In this article we argue that students who complete end of program assessments (EPAs) in North American library and information science (LIS) programs are more likely to experience certain positive early career outcomes after graduation than those who do not complete EPAs. EPAs are culminating courses, projects, or events that can help educators assess whether students have met program or degree objectives beyond the course-hour requirements. For the purpose of this paper, EPAs are defined as:

- internships

- program portfolios

- independent studies

- comprehensive examinations

- master's papers or theses, and

- other significant projects that share characteristics of the preceding, frequently called capstones among US and Canadian LIS educators.

Educational programs make significant investments of time and human resources in the development of competencies and the design of EPAs that can help students achieve program objectives, develop job skills and knowledge, and help the program measure student and institutional success. These investments lead to claims and assumptions, frequently anecdotal or based on the findings of one program, about the relative merits of a particular EPA. The findings from this study should be of interest to curriculum developers and program administrators in LIS programs worldwide, since they provide insight into the relative merits of EPAs and are based on aggregate data from 39 North American LIS programs. The statistical association of EPA completion and early career success measures we demonstrate in this research will help to convince students and faculty to prioritize end of program assessments when planning programs of study.

\section{Background}

EPAs exist in a variety of disciplines and forms across undergraduate, graduate, and certificate programs. Depending on the degree and discipline, the EPA is designed to increase the student's "soft skills" and "employability" (Thomas, Wong, \& Li, 2014). While much has been discussed about their potential benefits, (see Burke and Snead's (2014) extensive literature review of the advantages and disadvantages of each type as gauges for whether students meet overall program objectives and learning outcomes), little is known about measureable associations between the LIS EPA and subsequent career success across the field.

Burke and Snead (2014) researched faculty perceptions of EPAs in LIS master's programs and note that "some EPAs may assess students' knowledge and abilities more directly than others and there is a wide range of opinions among LIS faculty on the use and value of these assessments" (p. 26). The authors find that most LIS programs require one or more EPAs and conclude that if constrained to select only one EPA, full professors prefer portfolios while other faculty prefer research or fieldwork EPAs. Ideally, however, multiple EPA options would allow 
students to select the capstone experience that suits their academic and career goals. Additionally, the faculty surveyed express concerns about the impact that EPAs have on their grading workload and whether EPAs are truly serving their intended purpose.

\section{Internships}

Much has been written about the need in LIS programs for practical experience through internships, along with the benefits derived from participants on all sides (Bird \& Crumpton, 2014; Pacios, 2013; Yelinek \& Coffta, 2013). Unfortunately most of the literature provides the perspective from individual programs and small cohorts of student participants (Asher \& Alexander, 2006; Ball, 2008; Dalton \& Oehlerts, 2006; C. D. Lewis, 2006; Mark, 2005; Quarton, 2002) or suggests best practices for managing these capstones (Bastian, 2002; McGurr \& Damasco, 2010; Medaille, 2011; Scherrer, 2010; Williams, 2011). Research rarely reports on the efficacy of the internship as an EPA or student opinions on its value across programs or on a large scale. Follow-up studies of the impact of internships on career success (e.g., Gariepy, 2012) infrequently show up in the literature.

\section{Portfolios}

Portfolios have been shown to be useful reflective tools to help students in professional degree programs and other disciplines process their program experiences and provide evidence of achievement (Kajfez et al., 2013; Trevitt, Macduff, \& Steed, 2014; Wakimoto \& Lewis, 2014). Electronic or e-portfolios are particularly useful assessment tools for online degree programs and reports of individual program experiences and suggested best practices are plentiful (A. Lewis \& Strampel, 2014; Lim \& Lee, 2014; Shepherd \& Bolliger, 2014; Tyler \& Hoban, 2013). LIS programs that train school librarians claim success using portfolios and e-portfolios as EPAs (Jones, Downs, \& Repman, 2012; Keller, 2013), but few studies exist that show the usefulness of portfolios for other types of librarians and information professionals.

\section{Independent studies, comprehensive exams, master's theses, and other EPAs}

Deutsch, Nicholson, and the Association for Institutional Research (2006) describe how the use of traditional EPAs in master's degree programs is waning across the disciplines, perhaps as a result of the professionalization of these programs or changing models of higher education. Comprehensive exams and theses are rapidly being replaced by portfolios and other capstone projects that some argue are "more reliable, realistic tools for measuring what a student has learned during an extended period" (Deutsch et al., p. 9).

These programmatic changes in higher education are not without consequence. Tysick and Babb's (2006) case study at the University at Buffalo recognizes that librarians who are not trained in scholarly research and publication during their master's program via independent study or thesis preparation struggle in positions where scholarship and production of original research are required. Ivins (2014) wisely recommends that graduates "leverag[e] the research and writing effort exerted while studying for the master's degree" so that as new professionals they "can quickly build a strong foundation for their early-career publications" (p. 1). 


\section{Research Questions}

This research seeks to answer the following questions:

1. What EPAs have recent graduates completed (required and voluntary)?

2. How beneficial do graduates rate the EPAs?

3. For each type of EPA completed, how do graduates measure in terms of the following early-career outcome variables:

- length of time to secure employment after graduation

- acquisition of managerial or leadership roles

- level of professional activity and engagement in leadership activities (e.g., presenting at conferences, mentoring others, etc.)

- level of job/career satisfaction

4. Is the completion of a particular EPA during the LIS program associated with positive early career outcomes?

\section{Methods}

To answer these questions, we analyzed a subset of data from the Workforce Issues in Library and Information Science 2 Project (WILIS2). WILIS2 was a survey of alumni of 39 LIS programs in North America conducted in 2009-2010. The WILIS2 project team collaborated with LIS programs to design a survey that could be used with recent graduates to gather data on program evaluation, career preparation and progression, levels of professional engagement, job and career satisfaction, professional aspirations, and continuing education (see Marshall et al., 2010). Researchers asked the programs to provide contact information for a random sample of up to 250 of their graduates from the most recent five years; variability in alumni tracking practices and LIS program needs resulted in a sample of over 9,000 graduates from the years 2000-2009. The overall response rate to the survey was $40.5 \%(n=3,507)$, with individual program response rates ranging from $20 \%$ to $80 \%$. Although individual LIS programs track and analyze the career progression of alumni on a variable basis, the recently archived and publicly available WILIS2 data in aggregate provide researchers with a unique opportunity to examine LIS careers with a wider lens and test the viability of the dataset for secondary analyses.

The complete WILIS2 survey contained 7 sections of questions and 468 variables. To explore the potential relationships between completing one or more EPAs and the experience of positive early career outcomes, it was essential to focus primarily on the questions and variables measuring these phenomena. The salient questions about EPAs include the type of capstone(s) completed, whether it was a program requirement, and the graduate's perception of the benefits of completion. Answers to questions about the following factors provide data for the measurement of early career success: the length of time to secure employment post-program, the acquisition of managerial roles, the extent of participation in professional and leadership activities, and the level of job and career satisfaction. 
The analysis for this paper was conducted on a subset of the archived WILIS2 data (Marshall \& Morgan, 2012) using SPSS and manual coding of textual responses. The subset consists of graduates who earned their LIS master's degree between 2003 and 2009 and completed at least $93 \%$ of the survey to ensure their completion of all outcome variables $(n=3,226)$.

\section{Limitations}

This research analyzes data from a broadly focused alumni survey of North American programs only. The analysis was completed with the recognition that the research questions were exploratory in nature and that future research must be conducted that directly addresses the impact of EPAs on early career success. There may be intervening factors that could account for differences in early career outcomes that were either not captured by the survey or selected for analysis here. For example, geographic location and mobility of graduates were not collected, and individual programs are de-identified and not used as part of the analysis. It is also noted that graduates will have divergent impressions and experiences depending on the program they attend because of individual preferences, as well as key differences in the strengths, weaknesses, and administration of LIS programs.

\section{Results}

\section{Demographics}

Although these respondents are a bit younger than the average ALA member (54\% are 35 years old or younger), they are predominantly female (78\%) and White (87\%). The survey reached Canadian LIS program alumni and workers, but United States citizens represent the majority of respondents (83\%). 93\% are currently employed, 5\% are seeking employment, and 3\% are not working for pay but are engaged in other activities such as education, volunteering, or caregiving. Respondents are working in a variety of library and non-library settings: academic libraries (25\%), public libraries (24\%), school libraries (16\%), special libraries (10\%), archives and museums (4\%), non-library workplace (20\%), and self-employed (1\%). $18 \%$ of graduates completed all or most (more than half) of their courses online.

\section{Early career outcomes}

Overall, early career outcome variables trend positively. Most respondents got a job within 3 months of their first application (68\%) or by 3 months after graduation (75\%). Less than half (39\%) have supervisory or managerial roles; however, those who have these positions manage students or temporary employees (48\%), volunteers (36\%), paraprofessionals (38\%), and professionals (14\%).

Respondents were asked to select which of 19 different types of professional and leadership activities they have participated in since graduation; they also indicated which of 9 leadership responsibilities they have in their current job. A summative measure or "rate" of professional activity and leadership was calculated from these individual variables and the variables indicating different types of supervisory roles; an individual could score in the range of 0 to 32 . 
On average, respondents participate in 8.9 professional and leadership activities (range 0-29, median - 8; $s d-5.3$ ).

$88 \%$ agree that they are satisfied with what they do in their job, and only $13 \%$ indicate that they are likely to leave their current employer within a year. 95\% "like being a librarian/information professional" and $91 \%$ are satisfied with LIS as a career. Only 6\% plan on leaving LIS work in the next year, and $9 \%$ plan to leave LIS work within three years. Fewer respondents (87\%) indicated they would choose an LIS career if they "had it to do all over again," or encourage others to choose LIS as a career (84\%).

\section{End of program Assessments}

Depending on their program requirements and electives, students may complete any number of EPAs, and in different combinations. We will examine these combinations later in the paper, but first, an overview of individual EPAs in isolation is essential. Respondents most commonly completed the internship (80\%); respondent completion of other EPAs breaks down into the following categories: portfolio (33\%), independent study (32\%), comprehensive exam (29\%), a master's thesis/paper (15\%), and "other" (8\%). 9\% reported that they completed no EPA.

\section{Association between variables and statistical tests of significance}

To determine whether a selected EPA has any relationship to positive early career outcomes, respondents were grouped by whether or not they completed that particular EPA. We then conducted chi square tests of independence to see if there is an association between the completion of the EPA and the other categorical variables related to early career success (length of job search, supervisory role, types of professional and leadership activity, job/career satisfaction). We also conducted independent samples t-tests to determine whether there is an association between the completion of the EPA and the calculated rate of professional activity and leadership. A p-value less than .05 indicates a significant result in each type of test, and each variable was analyzed separately in conjunction with the EPA groups. Only associations with statistical significance $(p<.05)$ are outlined after each EPA result summary below and summarized in Table 1. Statistically significant associations that are unique to one particular type of EPA are followed by an asterisk $\left({ }^{*}\right)$.

\begin{tabular}{|l|l|}
\hline $\begin{array}{l}\text { Table } 1 . \\
\text { Summary of Statistically Significant Associations }\end{array}$ \\
$\begin{array}{l}\text { Type of End of } \\
\text { Program Assessment }\end{array}$ & Early Career Success Measure \\
$\begin{array}{l}\text { Graduates who } \\
\text { complete a/n... }\end{array}$ & are more likely than those who do not to... \\
\hline Internship & $\begin{array}{l}\text { - secure employment within } 3 \text { months of graduation }(p=.000) \\
\text { - secure employment within } 3 \text { months of first application }(p=.023)\end{array}$ \\
\hline
\end{tabular}




\begin{tabular}{|c|c|}
\hline & 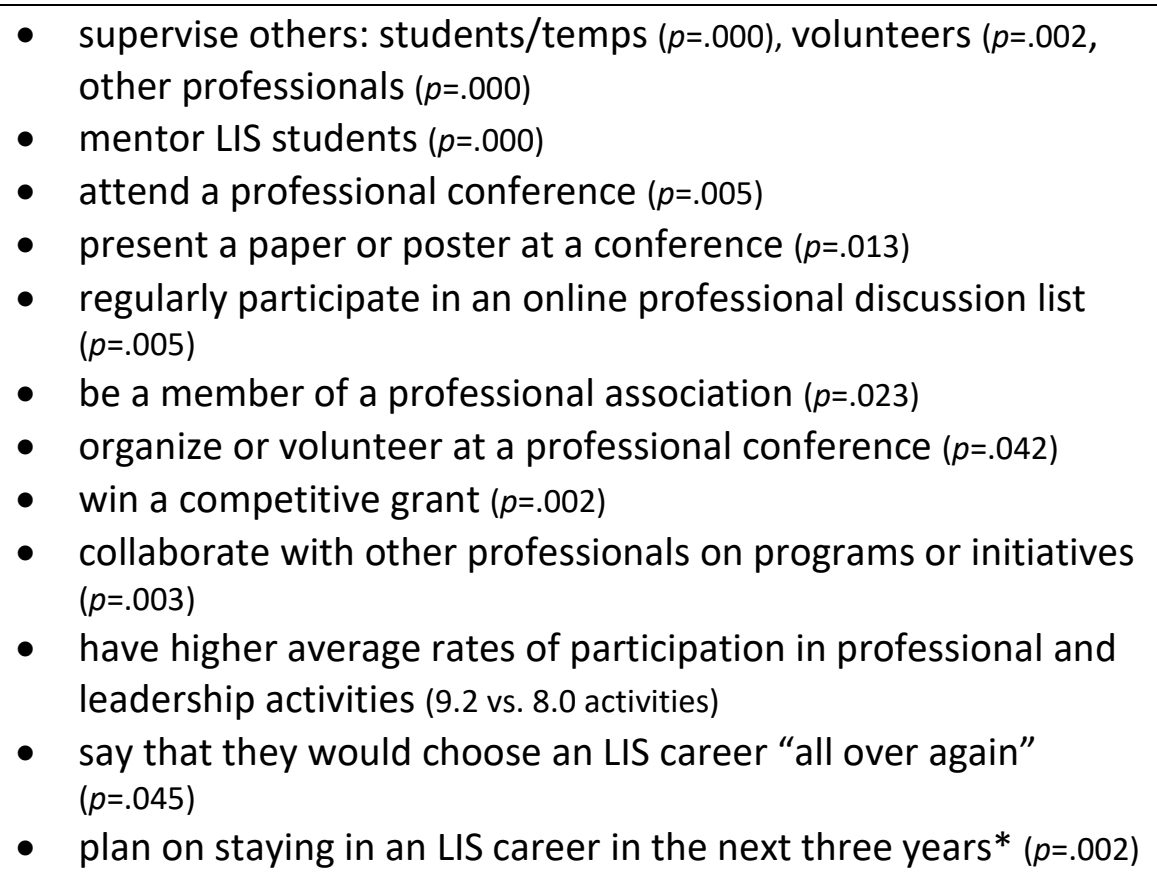 \\
\hline Portfolio/eportfolio & 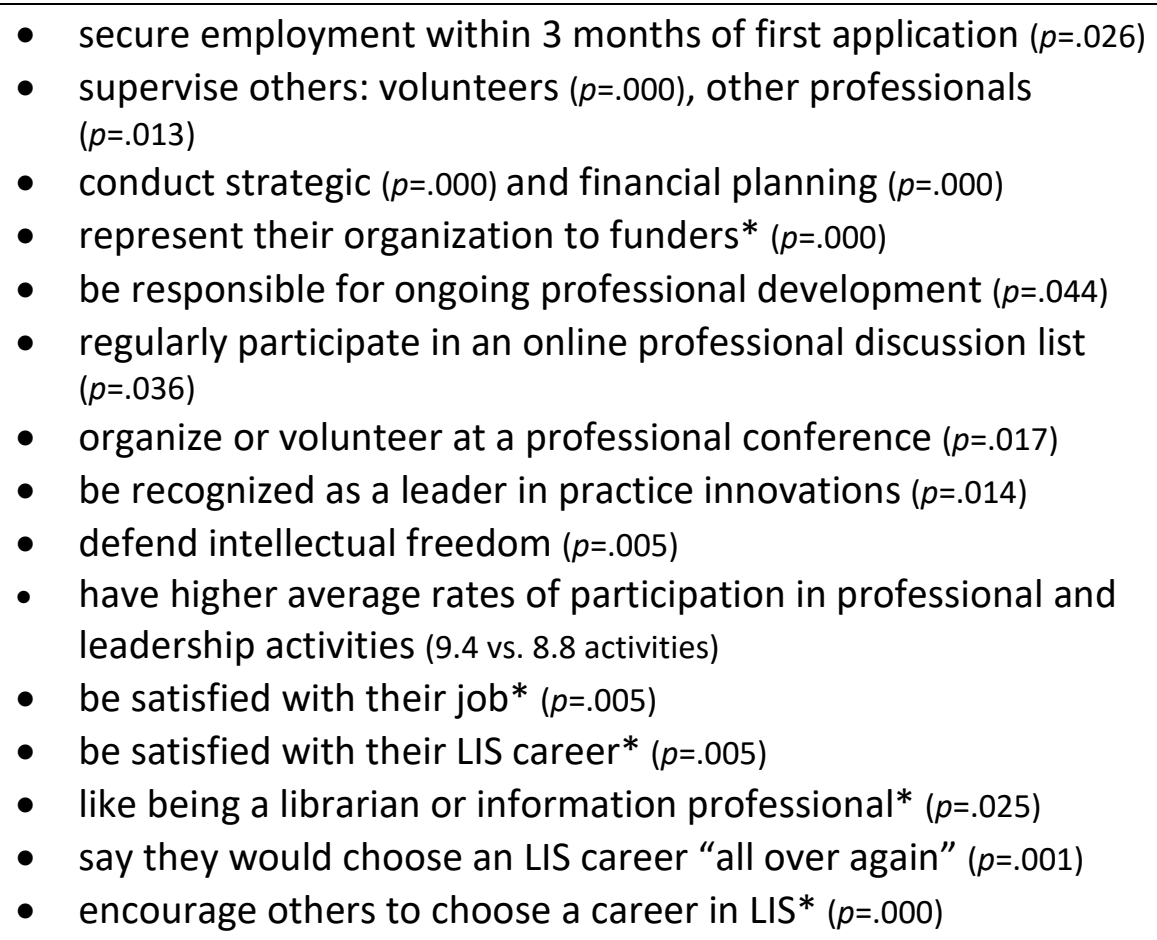 \\
\hline Independent study & $\begin{array}{l}\text { - } \text { secure employment within } 3 \text { months of graduation }(p=.000) \\
\text { - } \text { supervise others: students/temps }(p=.006) \text {, other professionals } \\
\text { ( } p=.039) \\
\text { - } \text { participate in strategic planning }(p=.000) \\
\text { - } \text { me responsible for ongoing professional development }(p=.034) \\
\text { mether professionals }(p=.000)\end{array}$ \\
\hline
\end{tabular}




\begin{tabular}{|c|c|}
\hline & 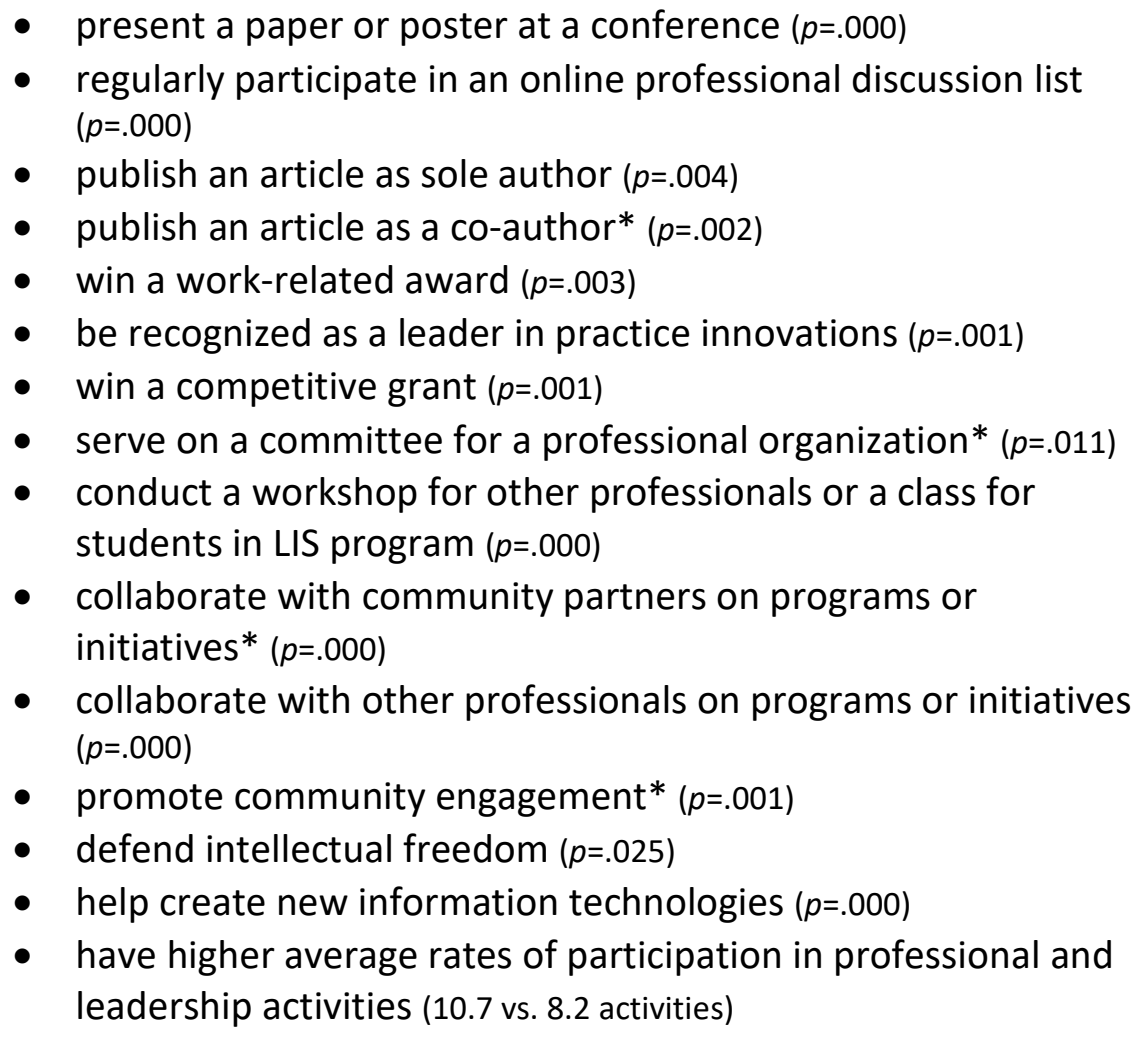 \\
\hline Comprehensive exam & 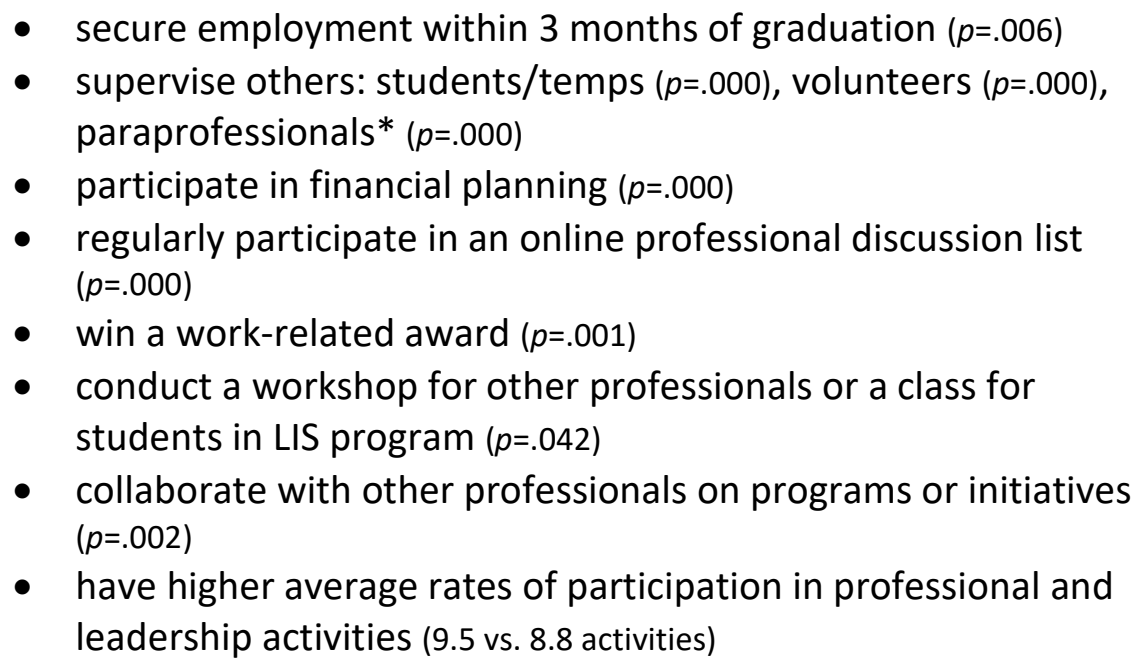 \\
\hline Master's paper/thesis & $\begin{array}{l}\text { - } \text { secure employment within } 3 \text { months of graduation }(p=.008) \\
\text { - } \text { participate in financial }(p=.002) \text { and strategic planning }(p=.008) \\
\text { - } \text { present a paper or poster at a conference }(p=.009) \\
\text { - } \text { publish an article as sole-author }(p=.003) \\
\text { - } \text { conduct a workshop for other professionals or a class for } \\
\text { students in LIS program ( } p=.032)\end{array}$ \\
\hline
\end{tabular}




\begin{tabular}{|c|c|}
\hline & $\begin{array}{l}\text { - have higher average rates of participation in professional and } \\
\text { leadership activities (9.7 vs. } 8.8 \text { activities) }\end{array}$ \\
\hline Other EPAs/capstones & $\begin{array}{l}\text { - } \text { secure employment within } 3 \text { months of graduation }(p=.000) \\
\text { - } \text { mentor LIS students }(p=.018) \text { and other professionals }(p=.023) \\
\text { - } \quad \text { present a paper or poster at a conference }(p=.005) \\
\text { - conduct a workshop for other professionals or a class for } \\
\text { - } \text { students in LIS program ( } p=.002) \\
\text { - help create new information technologies ( } p=.040) \\
\text { leadership activities ( } 10.1 \text { vs. } 8.9 \text { activities) }\end{array}$ \\
\hline \multicolumn{2}{|c|}{$\begin{array}{l}\text { Note. Statistically significant associations that are unique to one particular type of EPA are designated with an } \\
\text { asterisk }(*) \text {. }\end{array}$} \\
\hline
\end{tabular}

Internship

For the $80 \%$ of respondents who completed an internship ( $n=2581$ ), $46 \%$ were required by their program to complete it, and $67 \%$ received academic credit for the work experience. Students who take most or all of their coursework online are less likely to complete an internship. While $83 \%$ of those who take fewer than half of their courses online complete an internship, only $68 \%$ of the students who take most or all of their courses online complete one.

$88 \%$ rated the internship to be very beneficial, and only $1 \%$ considered their experience to be not at all beneficial. In their open-ended comments, respondents frequently praised the internship experience as "integral" or "the most valuable piece of [their] education," and several suggested that it should be "mandatory." Some respondents went on to obtain professional positions in the setting of their internship, while others became mentors to future interns. Negative comments about the internships were limited to the unfortunate experience of students who were mistreated or poorly mentored.

Respondents who complete an internship are significantly more likely than those who do not to secure employment within 3 months of graduation or first application, be a member of a professional association, mentor students, actively participate in an online professional discussion group, win a grant, collaborate with other professionals, and attend, organize, and present at conferences. They also have higher average rates of participation in professional and leadership activities (9.2 vs. 8.0). Former interns are significantly more likely to choose an LIS career "all over again" and to plan on staying in the career in the next three years.

\section{Portfolio or e-portfolio}


Of the $33 \%$ of respondents who completed a portfolio $(n=1076), 87 \%$ were required by their program to do so. The portfolio requirement may be related to whether the LIS program offers a significant portion of coursework online; $41 \%$ of the students who take most or all of their courses online complete a portfolio, compared to $32 \%$ of those who take fewer than half of their courses online.

$38 \%$ rated the portfolio to be very beneficial, but $12 \%$ considered their experience to be not at all beneficial. In the open-ended comments, one respondent revealed that the "e-portfolio landed me my job," while another assessed that it "allowed a valuable opportunity for reflection." Several said that the experience helped them as an information store during the job application and resume writing process. More often than not, however, respondents who were inspired to comment described the portfolio in negative terms, such as "pointless," or "busy work." Opinions about the usefulness of sharing the portfolio with potential employers were mixed. One respondent related that "my present employers were impressed with my portfolio. I was the only archivist to show up with one from the interview pool." Another shared that "it was not a tool I could use to find a job (which is how it was sold to us as incoming students)." Interestingly, several respondents who were not offered the option of completing a portfolio expressed disappointment and wished it were an elective part of their program.

Respondents who complete a portfolio are significantly more likely than those who do not complete one to secure employment within 3 months of first application, supervise the work of volunteers and other professionals, conduct strategic and financial planning, represent their organization to funders, hold responsibility for ongoing professional development, organize or volunteer at a conference, be recognized as a leader in practice innovations, defend intellectual freedom, and actively participate in an online professional discussion group. They have higher average rates of participation in professional and leadership activities (9.4 vs. 8.8). These findings suggest that these respondents may work as solo librarians in work settings that require volunteer staff; in fact, $28 \%$ of the portfolio completers are working in school libraries, compared to only $11 \%$ of those who do not complete the portfolio. All of the other work settings are similar between the two groups.

Graduates who complete portfolios are significantly more likely to be satisfied with their job and LIS career, to like being a librarian or information professional, to say they would choose an LIS career "all over again," and to encourage others to choose a career in LIS.

\section{Independent study}

For the $32 \%$ of respondents who completed an independent study ( $n=965$ ), 33\% were required by their program to do so. Students who take most or all of their coursework online are less likely to complete an independent study (23\%), compared to $34 \%$ of those who take who take fewer than half of their courses online.

$60 \%$ rated the independent study to be very beneficial, and only $4 \%$ considered their experience to be not at all beneficial. In their open-ended comments, respondents evaluated 
their independent study experiences as "invaluable" or "extremely helpful." Like the internship, respondent comments indicate that the overall quality of the independent study may depend on the level of mentorship given by the supervisor.

Respondents who complete an independent study have the highest average rate of participation in professional and leadership activities of all EPA groups at 10.7; those who do not complete an independent study average 8.2 , and are significantly more likely to say that they have "no leadership responsibilities" on the job. Graduates who complete an independent study are significantly more likely than those who do not to secure employment within 3 months of graduation, supervise students and other professionals, participate in strategic planning, work on professional organization committees, represent their organization and present papers or posters at conferences, publish an article as sole or co-author, win an award related to their work, be recognized as a leader in practice innovations, mentor other professionals, actively participate in an online professional discussion group, win a competitive grant, conduct a workshop, collaborate with other professionals and community partners, promote community engagement, defend intellectual freedom, and help to create new information technologies. Despite high levels of leadership activities, recognition, and professional engagement, these respondents are not more likely than their non-independent study peers to experience job and career satisfaction.

One reason for this high level of professional engagement may be related to work setting. Although the frequencies of most work settings are comparable between the independent study versus non-independent study groups, there is one notable difference; $27 \%$ of those who do not complete the independent study work in public libraries, compared to $20 \%$ of those who do complete one. Perhaps this finding is related to funding for professional activities, which can be a challenge for some public libraries.

\section{Comprehensive exam}

For the $29 \%$ of respondents who completed a comprehensive exam ( $n=879$ ), $88 \%$ were required by their program to do so. Students who completed most or all of their program online took the exam at nearly the same rate $(26 \%)$ as students who took primarily face-to-face courses (30\%). The comprehensive exam is by far the least popular of the EPAs from the student perspective; only $18 \%$ rated it to be very beneficial, and $26 \%$ considered the experience to be not at all beneficial. In the open-ended comments, very few respondents mentioned the exam, and those who did rarely discussed its virtues. Two graduates reflected that it was a useful way to "unify" and "synthesize" the program content. Several panned it, calling it "[in]effective," and "outdated." One student noted that the exam was mandated by the larger institution or other agency. The exam was occasionally compared unfavorably to another EPAs that graduates judged to be more useful or applicable.

Respondents who complete a comprehensive exam internship are significantly more likely to secure employment within 3 months of graduation, supervise others (students, volunteers, and paraprofessionals), participate in financial planning, actively participate in an online professional discussion group, receive a work-related award, conduct a workshop or training 
session for other professionals, and collaborate with other professionals. They have higher average rates of participation in professional and leadership activities (9.5 vs. 8.8).

\section{Master's thesis or paper}

The EPA with the lowest participation rate is the master's thesis or paper. Of the $15 \%$ of respondents who completed it ( $n=487), 77 \%$ were required by their program to do so. Students who completed most or all of their program online wrote the thesis at a similar rate (13\%) as students who took primarily face-to-face courses (16\%).

$53 \%$ rated the thesis to be very beneficial, and only $6 \%$ considered their experience to be not at all beneficial. Graduates regard the thesis mainly positively, in much the same way as they think of the internship or independent study. In the open-ended comments, one respondent describes the experience as giving "a sense of achievement." A student who regretted not completing a thesis recognized the benefits of the "intellectual rigor" required by the research and writing process. Another student used the thesis as an opportunity to prepare for future degree study. Again, negative comments related to the thesis were limited to the experience of students who were poorly advised or supervised.

Respondents who complete a master's thesis or paper are significantly more likely to secure employment within 3 months of graduation, participate in financial and strategic planning, present at conferences, be the sole-author of a published paper, win a work-related award, and conduct a workshop for other professionals or teach LIS students. They have higher average rates of participation in professional and leadership activities (9.7 vs. 8.8). A notable difference between the thesis and non-thesis groups is that $26 \%$ of the thesis writers work as school librarians compared to $15 \%$ in the non-writing group (more of whom are working in public libraries).

\section{Other EPAs}

$8 \%$ of respondents $(n=270)$ indicated that they completed "another" kind of EPA (required by the program for $62 \%$ of cases). Respondents described work experiences in libraries and archives, work showcases, practical hands-on or special projects, publishable papers, oral defenses, and extensive written examinations. Respondents used the comment section to describe more fully one or more of their significant or meaningful achievements during their LIS program. It is worth noting that the general tone expressed in the comments is one of pride and personal achievement.

$24 \%$ took most or all of their courses online, compared to $17 \%$ of those who did not complete the "other" EPA category; we might speculate that in some programs online students are afforded more freedom in their selection of a capstone experience, and this could account for their selection of "other," rather than one of the traditionally named EPA.

A brief overview of this group's results confirms that completing an EPA of any kind offers the student a greater likelihood of experiencing early career success. "Other capstone" respondents are significantly more likely to secure employment within 3 months of graduation, mentor 
students and other professionals, be a member of a professional association, present at conferences, conduct a workshop for other professionals, and help develop new technologies. They also have higher average rates of participation in professional and leadership activities (10.1 vs. 8.9). These respondents work in non-library settings at a slightly greater rate (25\%) than those who did not claim the "other" category (20\%). This may be an artifact of the survey design, which catered primarily to graduates who went on to work in libraries and archives.

\section{EPAs in combination and No EPAs completed}

Depending upon program requirements and elective options, students theoretically could complete multiple combinations of EPAs. The WILIS2 respondents sort into 58 different combinations. The most frequently occurring combinations are the internship only (19\%), the internship and portfolio (11\%), no EPAs (9\%), internship and independent study (8\%), internship and comprehensive exam (8\%), and internship, portfolio, and independent study (6\%). Given the high participation rate in the internship and the high number of unique combinations, there is little chance that further comparative analysis could yield other significant findings beyond what has been demonstrated in the analysis of EPAs in isolation.

Additionally, the respondents who did not complete any EPA were not isolated to a handful of programs. Instead, they represent 19 different LIS programs of the 39, a proportion that is equal to or just slightly fewer than that of the other most popular capstone combinations: internship only (22), the internship and portfolio (24), internship and independent study (19), internship and comprehensive exam (22), and internship, portfolio, and independent study (22).

\section{Discussion}

In summary, an analysis of career and program data from over 3,000 graduates (2003-2009) from 39 LIS programs is a large enough sample from which to draw some conclusions that will be of broad interest and potential applicability to LIS educators. Fortunately, the majority of graduates secure jobs before or relatively soon after graduation, are experiencing a variety of positive early career outcomes, and are satisfied in their jobs and careers; however, the results suggest that there may be some disparities in the early career successes of LIS graduates. These differential outcomes appear to be related to the opportunity or decision whether to complete one or more EPAs commonly implemented by LIS programs across North America. Specifically, the completion of a particular EPA is associated with selected positive early career outcomes that are experienced at a lower rate by the graduates who do not complete that same EPA.

Why might the completion of an internship or independent study be associated with getting a job sooner after graduation or increased participation in professional and leadership activities? Why are online students less likely to intern or complete an independent study? The answer may be related to the communities of practice that are embedded in the preparation for a capstone event and the experience of seeing it through to a successful completion. 
Internships, independent studies, and theses require the student to get outside the physical or virtual classroom and connect to new social networks. Students have to apply theoretical and practical knowledge to solve real problems. The apprenticeship experience builds a safe space for exploration, risk-taking, constructive criticism and feedback. An independent study, project, or substantial paper is another kind of safe space to learn the craft of writing and research with ongoing supervision; graduates can submit the vetted and completed product for publication or a grant, or use the project as the basis for a workshop. The student's research and writing competencies can be further refined in the professional or later academic setting.

Mentors and supervisors model professional engagement and introduce the mentee to colleagues and professional association activities. A certain amount of courage, internal motivation, persistence and interpersonal skill is required of the capstone participant that is not always asked of the student in the traditional classroom. If the portfolio is just a sorting and showcasing of old assignments, students may view it as an exercise with no practical utility. The student who completes any portfolio, however, shows greater potential for success in some areas; so it should be designed with the community of practice in mind so that it is applicable to the job search or to the achievement of program outcomes through reflective writing. Even the much-maligned comprehensive exam requires preparation, reflection, and re-engagement with issues and topics that are broader in scope than an individual course or selection of assignments.

Online students may be at a disadvantage if they and LIS program faculty are not able to promote and replicate these communities of practice at the same rate and consistency in the virtual environment as has happened in residential or hybrid programs. One such respondent wished for a "greater emphasis on practicum/internship and useful assistance from the school in locating these opportunities." It may take more effort to network, connect students to internships and mentors, and provide adequate support at a distance. LIS programs that have not had much experience or success with EPAs and online students may learn a great deal from peer institutions that have.

\section{Conclusions and recommendations}

These data suggest successful completion of any end of program assessment is associated with some positive early career outcomes, and particular choices are related to specific types of early career success. Perhaps well-structured and supported EPAs such as internships provide students with an extra edge in their knowledge base, skillset, interpersonal skills, and attitude; these extras may help them secure better jobs sooner, expose them to social networks, and give them the motivation to seek out opportunities for leadership and professional contribution. Independent research and writing projects may prove to be helpful to academic and other librarians who need that experience for tenure and promotion requirements. During the job search process, a completed portfolio might provide new graduates with a better sense of who they are professionally and of their most marketable strengths, and consequently, the weaknesses they need to address. 
Future research should be designed to parse out the relative merits of each capstone experience vis à vis certain career goals and work setting aspirations. North American LIS curriculum planners, administrators, and faculty should think carefully about the EPAs we offer our students and look to our international colleagues for their curricular strategies that result in early career success. The negative post-program experiences of some graduates, particularly online students, should concern educators. There are some areas that programs can strengthen to increase the likelihood that vulnerable students will also achieve career satisfaction and success. Assessment action items might include the critical analysis of:

- the number and type of EPA options offered

- individual or institutional biases for or against particular EPAs

- the infrastructure needed to continually support and assess EPA quality

- the quantity and quality of student advisement and EPA supervision

- program data that gauge early career outcome measures that are important to program mission and goals

- the existence of a rationale for choosing a particular EPA elective, along with evidence of its association with early career success outcomes

- equal opportunity, mentorship, advocacy, and support for all students to enroll in internships and independent studies (the most beneficial of all EPAs).

The preceding analyses suggest that EPA completion matters to early career success and satisfaction. Further, this paper illustrates the utility of secondary analyses of large-scale survey data to test assumptions, explore associations, and develop subsequent study designs that measure specific phenomena at a more precise and granular level. This research adds to the body of evidence we use to evaluate and refine our pedagogical frameworks, methods of program and student assessment, and the multiple ways we might measure early career success. 


\section{Works Cited}

Asher, C., \& Alexander, J. O. (2006). The library internship and expo as a pathway to diversity: A case study. Journal of Education for Library \& Information Science, 47(1), 17-26.

doi:10.2307/40324334

Ball, M. A. (2008). Practicums and service learning in LIS education. Journal of Education for Library \& Information Science, 49(1), 70-82. Retrieved from http://http://dpijournals.com/index.php/JELIS/

Bastian, J. A. (2002). Measuring the success of internships in an archives education program. Journal of Education for Library \& Information Science, 43(2), 164-174. doi:10.2307/40323977

Bird, N. J., \& Crumpton, M. A. (2014). Real learning connections: Questioning the learner in the LIS internship. Journal of Education for Library \& Information Science, 55(2), 89-99. Retrieved from http://http://dpi-journals.com/index.php/JELIS/

Burke, S. K., \& Snead, J. T. (2014). Faculty opinions on the use of master's degree end of program assessments. Journal of Education for Library \& Information Science, 55(1), 26-39. Retrieved from http://dpi-journals.com/index.php/JELIS/

Dalton, J. M., \& Oehlerts, B. (2006). A library internship: Perspectives from a library intern and a library supervisor. Colorado Libraries, 32(2), 42-44. Retrieved from http://www.coloradolibrariesjournal.org/

Deutsch, L. J., Nicholson, B. L., \& Association for Institutional Research. (2006). The changing nature of the comprehensive assessment as the culminating experience for the acquisition of the master's degree. IR Applications. Volume 8. Retrieved from http://eric.ed.gov/?id=ED504376

Gariepy, L. W. (2012). The Environmental Protection Agency/National Institute of Environmental Health Sciences Libraries Internship Program: An analysis of former interns' careers. Journal of Education for Library \& Information Science, 53(1), 20-31. Retrieved from http://dpijournals.com/index.php/JELIS/

Ivins, T. (2014). Upcycling MSLS coursework into publishable content. Endnotes: The Journal of the New Members Round Table, 5(1), 1-16. Retrieved from http://www.ala.org/nmrt/oversightgroups/comm/schres

Jones, S. A., Downs, E., \& Repman, J. (2012). The evolution of ePortfolios for school library education: A case study. School Libraries Worldwide, 18(2), 12-20. Retrieved from http://www.iaslonline.org/publications/slw/index.html

Kajfez, R. L., Mahnas J, M.-A., Brown, P. R., Mann, K. A., Carrico, C. A., Cross, K. J., . . McNair, L. D. (2013). Assessing graduate engineering programs with ePortfolios: A comprehensive design process. Advances in Engineering Education, 3(3), 1-29. Retrieved from http://advances.asee.org/

Keller, C. A. (2013). E-Portfolios for reflective practice, advocacy, and professional growth. School Library Monthly, 29(6), 8-10. Retrieved from http://staging.schoollibrarymedia.com/ 
Lewis, A., \& Strampel, K. (2014). Implementation of an ePortfolio. Journal of Clinical Practice in SpeechLanguage Pathology, 16(3), 139-146. Retrieved from http://www.speechpathologyaustralia.org.au/publications/jcpslp

Lewis, C. D. (2006). Internship programs: Ideas and strategies from the intern's perspective. Visual Resources Association Bulletin, 33(3), 12-14. Retrieved from http://online.vraweb.org/vrab/

Lim, C. P., \& Lee, J. C.-K. (2014). Teaching e-portfolios and the development of professional learning communities (PLCs) in higher education institutions. Internet \& Higher Education, 20, 57-59. doi:10.1016/j.iheduc.2013.10.002

Mark, A. E. (2005). Libraries without walls: An internship at Oshkosh Correctional Institution Library. Behavioral \& Social Sciences Librarian, 23(2), 97-111. doi:10.1300/J103v23n02_06

Marshall, J. G., \& Morgan, J. C. (2012). Workforce Issues in Library \& Information Science 2 (WILIS 2). Retrieved from: http://hdl.handle.net/1902.29/10438

Marshall, J. G., Morgan, J. C., Rathbun-Grubb, S., Marshall, V. W., Barreau, D., Moran, B. B., . . . Thompson, C. A. (2010). Toward a shared approach to program evaluation and alumni career tracking: Results from the Workforce Issues in Library and Information Science 2 Study. Library Trends, 59(1/2), 30-42. Retrieved from https://www.press.jhu.edu/journals/library trends/

McGurr, M. J., \& Damasco, I. T. (2010). Improving the practicum or internship experience in cataloging. Technical Services Quarterly, 27(1), 1-16. doi:10.1080/07317130802679041

Medaille, A. (2011). Field experiences provide value for library students, but more research Is needed into their administration. Evidence Based Library \& Information Practice, 6(2), 69-71. Retrieved from https://ejournals.library.ualberta.ca/index.php/EBLIP

Pacios, A. R. (2013). Assessment of the practicum by students from the perspective of the induction process. Journal of Education for Library \& Information Science, 54(3), 191-204. Retrieved from http://dpi-journals.com/index.php/JELIS/

Quarton, B. (2002). Five steps to an effective internship program. College \& Research Libraries News, 63(2), 109-111. Retrieved from http://crln.acrl.org/

Scherrer, C. S. (2010). Evaluating a health sciences library residency program: what have we learned? Journal of the Medical Library Association, 98(4), 300-302. doi:10.3163/1536-5050.98.4.006

Shepherd, C. E., \& Bolliger, D. U. (2014). Managing communication and professional development in online graduate programs with electronic portfolios. Online Journal of Distance Learning Administration, 17(2), 72-80. Retrieved from http://www.westga.edu/ distance/ojdla/

Thomas, K., Wong, K.-C., \& Li, Y.-c. (2014). The capstone experience: student and academic perspectives. Higher Education Research \& Development, 33(3), 580-594. doi:10.1080/07294360.2013.841646

Trevitt, C., Macduff, A., \& Steed, A. (2014). [e]portfolios for learning and as evidence of achievement: Scoping the academic practice development agenda ahead. Internet \& Higher Education, 20, 6978. doi:10.1016/j.iheduc.2013.06.001

Tyler, C., \& Hoban, G. (2013). Using an electronic portfolio to translate theory into practice for fieldwork In educational administration. ICICTE Proceedings, 247-256. Retrieved from http://www.icicte.org/Proceedings2013/HOME2013.htm 
Tysick, C., \& Babb, N. (2006). Writing support for junior faculty librarians: A case study. Journal of Academic Librarianship, 32(1), 94-100. doi:10.1016/j.acalib.2005.10.005

Wakimoto, D. K., \& Lewis, R. E. (2014). Graduate student perceptions of eportfolios: Uses for reflection, development, and assessment. Internet \& Higher Education, 21, 53-58. doi:10.1016/j.iheduc.2014.01.002

Williams, H. R. (2011). Structure may be key to incorporating library school interns in academic library environments. Evidence Based Library \& Information Practice, 6(3), 59-60. Retrieved from https://ejournals.library.ualberta.ca/index.php/EBLIP

Yelinek, K., \& Coffta, M. (2013). The value of graduate internships in creating online tutorials. College \& Research Libraries News, 74(11), 558-576. Retrieved from http://crln.acrl.org/ 